УДК 342.9

DOI https://doi.org/10.32849/2663-5313/2021.4.29

\title{
Володимир Репело,
}

ад’юнкт

Дніпропетровського державного університету внутрішніх справ

\section{АДМІНІСТРАТИВНО-ПРАВОВИЙ СТАТУС ДЕРЖАВНОЇ МІГРАЦЙНОЇ СЛУЖБИ УКРАЇНИ}

Метою статті є визначення адміністративно-правового статусу Державної міграчійної служби України та відповідних нормативно-правових актів, які містять норми, які ией статус урегульовують. У статті йдеться про адміністративно-правовий статус Державної міграційної служби України. Визначено категоріальний апарат проблематики, наведено визначення понять «правовий статус», «адміністративно-правовий статус» із джерел енииклопедичного характеру, а також позицї щодо цвого дослідників адміністративного та міграційного права (С. Гусаров, М. Єфремова, О. Воронятнікова). Встановлено, що під правовим статусом здебільшого розглядається сукупність визначених і законодавчо закріплених прав, свобод, обов'язків та відповідальностей, які визначають правове становище юридичної особо (Державної міграчійної служби України), а правовий статус юридичних осіб визначається через ї компетениію. Наведено позииії авторів щодо визначення поняття «адміністративно-правовий статус Державної міграиійної служби України». Висвітлено елементи адміністративно-правового статусу Державної міграчійної служби Украӥни, такі як призначення, функиії, організачія діяльності, компетениія та юридична відповідальність посадових осіб, які пращюють у Державній міграчійній службі України та надають адміністративні послуги у сферах міграції, громадянства, реєстрачії фізичних осіб, біжениів. Акцентовано увагу на тому, що Державна міграчійна служба України серед иентральних органів виконавчої влади діє в системі Міністерства внутрішніх справ, а функиіями служби можна назвати реалізаиію державної політики у сферах міграчії та нелегальній мігращії, громадянства, реєстрацї̈ фізичних осіб, біженщів шляхом здійснення адміністративної діяльності. Встановлено, що повноваження визначені не лише в Положенні про Державну міграційну службу, але й в інших нормативно-правових актах. Зазначено, що посадові особи несуть відповідальність на загальних засадах державної служби (кримінальну, адміністративну, дисциплінарну тощо).

Ключові слова: компетенція, повноваження, функції, права та обов'язки, організація діяльності, відповідальність.

Постановка проблеми. Україна взяла курс із отриманням незалежності на розбудову демократичної правової держави, а одним з елементів такої держави є міграційна політика держави. Державна міграційна служба України виконує широкий спектр різних адміністративних послуг, а її ефективна діяльність у системі Міністерства внутрішніх справ є однією з умов, за яких Україна продовжує євроінтеграційні процеси.

Після 2014 р. Державна міграційна служба України зазнала змін, було прийнято нове Положення, яке регулює основні аспекти іï адміністративної діяльності, отже, в історичному контексті можна вважати, що зміни відбулись нещодавно й науковий доробок з адміністративного права потребує в подальшому висвітлення правового статусу Державної міграційної служби України, сфер відання, структури, завдань та повноважень щодо нової державної інституції.

Актуальність дослідження посилюється не лише важливістю цього центрального органу виконавчої влади як надавача громадянам адміністративних послуг, адже українці беруть активну участь у трудовій міграції, тому мільйони громадян щорічно потребують отримання послуг саме цієї структури. Водночас ефективність діяльності служби залежить від наукового аналізу чинних нормативних актів, які таку діяльність врегульовують, та висвітлення шляхів покращення нормативно-правової бази.

До наукового доробку, де висвітлюються питання адміністративно-правового статусу Державної міграційної служби України, належать праці В. Авер'янова, О. Воронятнікова, В. Галунько, С. Гусарова, П. Діхтієвського, М. Єфремової, А. Комзюк, Є. Подорожнього, О. Салманова.

\footnotetext{
Метою статті $є$ визначення адміністративно-правового статусу Державної міграційної служби України та відповідних нормативно-правових актів, які містять норми, які цей статус урегульовують.
} 
Виклад основного матеріалу. Перед тим як розглядати безпосередньо адміністративно-правовий статус Державної міграційної служби, варто зупинити увагу на категоріальному апараті цього наукового дослідження. В юридичній енциклопедії під правовим статусом визначається сукупність прав та обов'язків фізичних і юридичних осіб. Правовий статус юридичних осіб визначається через іiі компетенцію (права та обов'язки, визначені у нормативних актах про органи державної влади). В енциклопедії підкреслюється, що саме від повноти юридичної фіксації повноважень юридичних осіб залежить ефективність їхньої діяльності [10].

Поняття правового статусу використовувалось ще у Стародавньому Римі, з латини «статус» перекладається як «становище», «стан у ієрархії, структурі, системі». Вчені в Римі використовували це поняття для відображення правового становища особи на кшталт стану громадянства (status civitatus). Вже на початку XX ст. поняття «статус» у науковий доробок ввели американські соціологи, зокрема Р. Лінтон [1, с. 31].

М. Єфремова зазначає, що питання змісту та структури адміністративно-правового статусу органу має велике значення для вирішення проблем удосконалення організації його діяльності, корегування місця в загальній системі органів державної влади та підвищує результативність його діяльності [2, с. 192]. О. Воронятніков наводить авторське бачення поняття «правовий статус»: «поняття «правовий статус» слід розуміти як сукупність законодавчо закріплених прав, свобод, обов'язків і відповідальності, які визначають правове становище фізичної або юридичної особи» [1, с. 33]. Адміністративно-правовий статус дослідник вважає одним із різновидів саме правового статусу, якому, окрім загальних рис, що притаманні правовому статусу, властива низка особливостей та специфічних рис. Основою адміністративно-правового статусу дослідники 3 адміністративного права вважають комплекс конкретно визначених суб'єктних прав та обов'язків, що закріплені за відповідним суб'єктом адміністративного права. Також до елементів адміністративно-правового статусу науковці додають гарантії реалізації зазначених прав та обов'язків [1, с. 33]. О. Воронятніков зазначає, що «адміністративно-правовий статус слід розуміти як спеціальний стан суб'єкта, що відображає становище суб'єкта правових відносин (з відповідними правами й обов'язками) у сфері публічного управління» [1, с. 35].

О. Корєнєв вказує на те, що адміністративно-правовий статус органу виконавчої влади визначається його конкретним призначенням, місцем і роллю в системі управління, a загальними рисами правового статусу є підзаконний характер діяльності органів виконавчої влади; наділення його правом видавати підзаконні акти; підзвітність і підконтрольність органу нижчого щабля вищому; оперативна самостійність органу в межах його компетенції. Ю. Битяк вважає, шо правовий статус органу виконавчої влади виражається в їх компетенції (предмети відання, права, обов'язки, територіальні межі діяльності органу влади) [2, с. 193].

О. Воронятніков про Державну міграційну службу зазначає, що «адміністративноправовим статусом Державної міграційної служби України є визначена нормами адміністративного права компетенція - предмети відання, права й обов'язки (повноваження); відповідальність за дії чи бездіяльність у межах власної чи делегованої компетенції; публічні, виконавчо-розпорядчі, дозвільнореєстраційні, контрольні функції у сфері міграції» $[1$, с. 36]. Варто зауважити, що автор писав про контролюючі повноваження ще до того часу, коли такі повноваження були забрані. М. Єфремова зазначає, що «під адміністративно-правовим статусом Державної міграційної служби України слід розуміти ієрархічне положення останньої у системі органів виконавчої влади, яке визначається сукупністю адміністративно-правових норм, що закріплюють призначення, функції, організацію діяльності, компетенцію та юридичну відповідальність посадових осіб щодо надання адміністративних послуг у сферах міграції, громадянства, реєстрації фізичних осіб, біженців тощо» [2, с. 193]. Відштовхуючись від наведеного визначення, зазначаємо, що серед елементів адміністративно-правового статусу Державної міграційної служби України є призначення, функції, організація діяльності, компетенція та юридична відповідальність посадових осіб, які працюють у Державній міграційній службі України та надають адміністративні послуги у сферах міграції, громадянства, реєстрації фізичних осіб, біженців [2, с. 193]

Отже, визначення М. Єфремової передбачає ширший спектр елементів адміністративно-правового статусу Державної міграційної служби, тому ми будемо розглядати його, відштовхуючись від зазначених дослідницею елементів. Відповідно до Положення про Державну міграційну службу України 2014 р., Державна міграційна служба України (ДМС) є центральним органом виконавчої влади, діяльність якого спрямовується та координується Кабінетом Міністрів України через Міністра внутрішніх справ, який 
реалізує державну політику у сферах міграції (імміграції та еміграції), у тому числі протидії нелегальній (незаконній) міграції, громадянства, реєстрації фізичних осіб, біженців та інших визначених законодавством категорій мігрантів (п. 1 Положення) [6]. Таким чином, Державна міграційна служба України серед центральних органів виконавчої влади діє в системі Міністерства внутрішніх справ а функціями служби можна назвати реалізацію державної політики у сферах міграції та нелегальної міграції, громадянства, реєстрації фізичних осіб, біженців шляхом здійснення адміністративної діяльності. Державна міграційна служба України в такій адміністративної діяльності керується Конституцією, Законами України, актами Президента України і Кабінету Міністрів України, наказами Міністерства внутрішніх справ, іншими актами законодавства, дорученнями Президента України та Міністра внутрішніх справ [4, с. 64]. М. Єфремова наводить також функції Державної міграційної служби відповідно до сфери державної політики, яку реалізує служба, та покладених завдань. Зокрема, ними є надання адміністративних послуг у сферах міграції, громадянства, реєстрації фізичних осіб, біженців [2, с. 194].

Відповідно до п. 3 Положення про Державну міграційну службу України, на неі покладені два такі основні завдання, як «реалізація державної політики у сферах міграції (імміграції та еміграції), у тому числі протидії нелегальній (незаконній) міграції, громадянства, реєстрації фізичних осіб, біженців та інших визначених законодавством категорій мігрантів; внесення на розгляд Міністра внутрішніх справ пропозицій щодо забезпечення формування державної політики у сферах міграції (імміграції та еміграції), у тому числі протидії нелегальній (незаконній) міграції, громадянства» [6].

Питання організації діяльності також врегульовані нормами Положення про Державну міграційну службу, про затвердження Типового положення про територіальні органи міністерства та іншого центрального органу виконавчої влади [8] 2011 р., про утворення територіальних органів Державної міграційної служби [9] 2011 р. У Положенні не існує окремого пункту, який би визначав організаційну структуру Державної міграційної служби України, однак дослідники на основі аналізу норм Положення наводять таку організаційну структуру: територіальні органи (головні управління), управління міграційної служби в АР Крим, областях, м. Киві та м. Севастополі; територіальні підрозділи (відділи або управління в районах районах у містах, містах обласного, республі- канського значення; апарат служби; пункти тимчасового перебування іноземців; державні підприємства, установи та організації) [2, c. 194].

Наступним елементом адміністративноправового статусу є компетенція Державної міграційної служби України. В юридичній енциклопедії під компетенцією розглядається «сукупність установлених в офіційній - юридичній чи неюридичній - формі прав і обов'язків, тобто повноважень будьякого органу або посадової особи, які визначають можливості цього органу або посадової особи приймати обов'язкові до виконання рішення, організовувати та контролювати їх виконання, вживати у необхідних випадках заходів відповідальності тощо. Компетенція державних органів (органів місцевого самоврядування) та їх посадових осіб встановлюється правовими актами, отже, їі реалізація забезпечується засобами державного примусу < ...> Основною формою реалізації державними органами своєї компетенції $€$ видання ними правових (нормативних та індивідуальних) актів, а особами - здійснення організаційно-розпорядчих дій щодо підлеглих їм суб'єктів» [3].

Авторський колектив на чолі з С. Гусаровим зазначає, що ядром правового статусу будь-якого суб'єкта права є права та обов'язки. Колектив називає повноваження Державної міграційної служби України колом прав та обов'язків, які служба реалізує та виконує щодо суб'єктів, які перебувають поза межами їі системи, й стосовно суб'єктів, які перебувають у їі безпосередньому підпорядкуванні [5, с. 127]. Пункт 4 Положення визначає коло повноважень відповідно до поставлених перед Державною міграційною службою завдань, усього 39 підпунктів. Також задля організації діяльності вона «забезпечує в межах повноважень, передбачених законом, здійснення заходів щодо запобігання корупції і контроль за їх реалізацією в апараті ДМС, її територіальних органах та територіальних підрозділах, на підприємствах, в установах та організаціях, що належать до сфери ії управління; організовує проведення конкурсу на зайняття вакантних посад державної служби <..>, в установленому порядку призначає керівників підприємств, установ та організацій, що належать до сфери її управління, забезпечує в межах повноважень, визначених законом, організацію підвищення рівня професійної компетенції державних службовців і працівників апарату ДМС, ії територіальних органів; контролює та координує діяльність територіальних органів та територіальних підрозділів ДМС; надає територіальним 
органам та територіальним підрозділам методичну і практичну допомогу, проводить перевірки їх діяльності; організовує плановофінансову роботу $<\ldots>$, здійснює контроль за використанням фінансових і матеріальних ресурсів, забезпечує організацію та вдосконалення бухгалтерського обліку в установленому законодавством порядку; взаємодіє з громадськими об'єднаннями та міжнародними неурядовими організаціями, в тому числі тими, що надають гуманітарну та інші види допомоги біженцям та іншим категоріям мігрантів, шляхом реалізації спільних проєктів (програм); забезпечує у межах повноважень, передбачених законом, виконання завдань мобілізаційної підготовки та мобілізаційної готовності держави; організовує ведення діловодства та архівне зберігання документів в апараті ДМС відповідно до встановлених правил» [6].

Пунктом 6 встановлені такі права Державної міграційної служби для виконання покладених на неї завдань:

1) «залучати в установленому порядку до виконання окремих робіт, участі у вивченні окремих питань вчених і фахівців, працівників центральних та місцевих органів виконавчої влади, органів місцевого самоврядування, а також підприємств, установ та організацій (за погодженням з їх керівниками);

2) одержувати безоплатно від державних органів та органів місцевого самоврядування, підприємств, установ та організацій незалежно від форми власності та їх посадових осіб, а також від громадян та їх об’єднань інформацію, документи і матеріали, необхідні для виконання покладених на ДМС завдань;

3) скликати наради, утворювати комісії та робочі групи, проводити наукові конференції, семінари з питань, що належать до її компетенції;

4) користуватися відповідними інформаційними базами даних державних органів, державною системою урядового зв'язку та іншими технічними засобами;

5) проводити перевірки стану додержання органами виконавчої влади, громадянами, органами реєстрації, підприємствами, установами та організаціями вимог законодавства у сферах міграції (імміграції та еміграції), у тому числі протидії нелегальній (незаконній) міграції, громадянства, реєстрації фізичних осіб, біженців та інших визначених законодавством категорій мігрантів і вносити пропозиції щодо усунення причин порушення таких вимог;

6) ініціювати проведення спільних перевірок 3 правоохоронними органами та іншими центральними органами виконав- чої влади у межах повноважень, передбачених законом;

7) створювати умови для тимчасового тримання іноземців та осіб без громадянства, затриманих за незаконне перебування на території України, до вирішення питання щодо їх примусового видворення або поміщення до пункту тимчасового перебування іноземців та осіб без громадянства, які незаконно перебувають в Україні, шляхом виділення приміщень в територіальних органах ДМС» [6].

Повноваження та завдання визначаються також в інших актах, наприклад у ст. 24 Закону «Про громадянство України» 2001 р. зазначено такі повноваження центрального органу виконавчої влади, що реалізує державну політику у сфері громадянства, тобто Державної міграційної служби України:

- «встановлення належності до громадянства України;

- прийняття заяв разом із необхідними документами щодо прийняття до громадянства України, виходу з громадянства України дітей у випадках, передбачених ч. ч. 10-12 ст. 18 цього Закону, перевірки правильності оформлення документів, наявності умов для прийняття до громадянства України і відсутності підстав, з яких особа не приймається до громадянства України, наявності підстав для виходу з громадянства України і відсутності підстав, з яких не допускається вихід з громадянства України, надсилання заяв разом зі своїм висновком на розгляд Комісії при Президентові України з питань громадянства;

- підготовка подань про втрату особами громадянства України і разом із необхідними документами надсилання їх на розгляд Комісії при Президентові України з питань громадянства» [7].

Щодо питань відповідальності посадових осіб Державної міграційної служби України варто зауважити, що відповідальність поширюється на загальних засадах, які діють відповідно до законодавства про державну службу.

\section{Висновки}

Отже, Державна міграційна служба України $€$ центральним органом виконавчої влади, який діє в системі Міністерства внутрішніх справ, а її функції стосуються реалізації державної політики у сферах міграції, громадянства, реєстрації фізичних осіб, біженців. Відповідно до поставлених завдань та сфер відання, Положення про Державну міграційну службу та інші акти містять норми щодо повноважень, тобто прав та обов'язків цієї державної інституції. Недоліком є відсутність окремого пункту в Положенні щодо структури Державної міграційної служби України. 


\section{Список використаних джерел:}

1. Воронятніков О. Правовий статус Державної міграційної служби України. Науковий вісник Національної академї внутрішніх справ. 2011. № 6. C. 31-37.

2. Єфремова М. Адміністративно-правовий статус Державної міграційної служби України у системі органів публічної адміністрації. Митна справа. 2015. № 3 (2). С. 210-214.

3. Компетенція. Юридична енииклопедія : в 6 т. / редкол.: Ю. Шемшученко (голова редкол.) та ін. Київ : Українська енциклопедія, 1998. URL: https://leksika.com.ua/16890902/legal/ kompetentsiya.

4. Максименко А. Адміністративно-правовий статус Державної міграційної служби України. Правова держава. 2015. № 19. С. 63-68.

5. Гусаров С., Комзюк А., Салманова О. та ін. Міграційне право України : підручник. Харків : Дім реклами, 2016. 296 с.

6. Положення про Державну міграційну службу України : затв. Постановою Кабінету Міні- стрів України від 20 серпня 2014 р. № 360. URL: https://zakon.rada.gov.ua/laws/show/360-2014$\% \mathrm{D} 0 \% \mathrm{BF}$ Text.

7. Про громадянство України : Закон України від 18 січня 2001 р. № 2235-III. URL: https:// zakon.rada.gov.ua/laws/show/2235-14\#Text.

8. Про затвердження Типового положення про територіальні органи міністерства та іншого центрального органу виконавчої влади : Постанова Кабінету Міністрів України від 25 травня 2011 p. № 563. URL: https://zakon.rada.gov.ua/ laws/show/563-2011-\%D0\%BF\#Text.

9. Про утворення територіальних органів Державної міграційної служби : Постанова Кабінету Міністрів України від 15 червня 2011 p. № 658. URL: https://zakon.rada.gov.ua/ laws/show/658-2011-\%D0\%BF\#Text.

10. Шемшученко Ю., Пархоменко Н. Правовий статус. Юридична енииклопедія : в 6 т. / редкол.: Ю. Шемшученко (голова редкол.) та ін. Київ:Українськаенциклопедія, 1998.URL:https:// leksika.com.ua/10940217/legal/pravoviy_status.

Volodymyr Repelo. The administrative and legal status of the state migration service of Ukraine

The purpose of the article is to determine the administrative and legal status of the State Migration Service of Ukraine and the relevant regulations that contain rules that regulate this status. The article deals with the administrative and legal status of the State Migration Service of Ukraine. The categorical apparatus of the problem is determined, the definitions of "legal status", "administrative-legal status" from encyclopedic sources, as well as opinions on this issue by researchers of administrative and migration law (S. Gusarov, M. Efremov, O. Voronyatnikov and others). It is established that the legal status is mostly considered to be a set of certain legally enshrined rights, freedoms and responsibilities that determine the legal status of a legal entity (State Migration Service of Ukraine), and the legal status of legal entities is determined by its competence. The opinions of the authors on the definition of "administrative and legal statute of the State Migration Service of Ukraine" are given. Elements of the administrative and legal status of the State Migration Service of Ukraine are highlighted: appointment, functions, organization of activities, competence and legal responsibility of officials working in the State Migration Service of Ukraine and providing administrative services in migration, citizenship, registration of individuals, refugees. It is emphasized that the State Migration Service of Ukraine among the central executive bodies operates in the system of the Ministry of Internal Affairs, and the functions of the service include the implementation of state policy in the areas of migration and illegal migration, citizenship, registration of individuals, refugees through administrative activities. It is established that the powers are defined not only in the Regulations on the State Migration Service, but also in other regulations. It is noted that officials are responsible on the general basis of the civil service (criminal, administrative, disciplinary, etc.).

Key words: competence, powers, functions, rights and responsibilities, organization of activity, responsibility. 